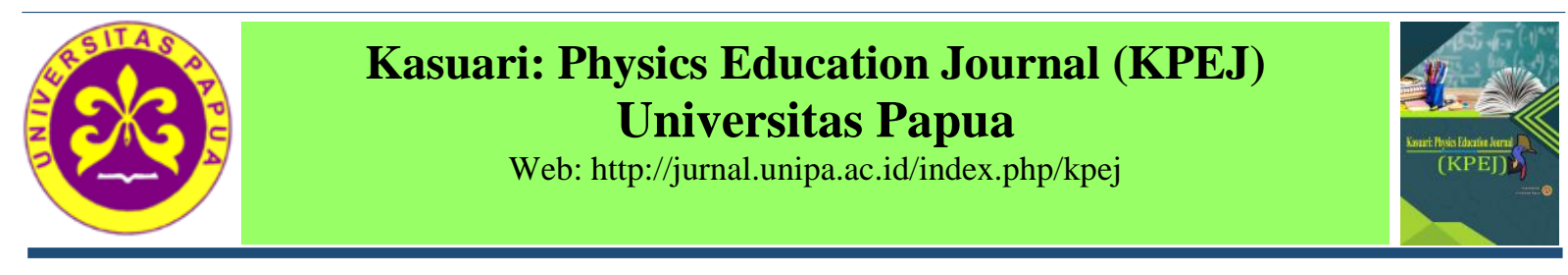

\title{
Development of Cadets Worksheets based on Problem Centered Learning as Applied Physics Learning Media
}

\author{
Nelfi Erlinda*, Budi Rianto, \& Dody Efrianto \\ Politeknik Pelayaran Sumatera Barat \\ *Corresponding author: nelfierlinda02@gmail.com
}

\begin{abstract}
The purpose of this study to develop valid and practical Cadets Worksheets based on Problem Centered Learning. This type of research was a Research and Development $(R \& D)$ research, which uses six research steps: potential problems, information gathering, product design, design validation, design improvement, and testing. The research instrument used was a questionnaire of validity and questionnaire of practicability. Analysis techniques used to test the validity and practicality of learning materials developed student worksheet was Likert-scale analysis techniques. Based on validation data analysis by validator obtained average percentage value of Cadets Worksheet was 83,6\% (very valid). The result of Cadets Worksheet practice percentage by students' was $83.4 \%$ (very practical). Based on the above data analysis can be concluded that Worksheet Physics based PCL developed valid and practical.
\end{abstract}

Keywords: Problem-Centered Learning, Worksheet

\section{Pengembangan Lembar Kerja Taruna berbasis Problem Centered Learning sebagai Media Pembelajaran Fisika Terapan}

\begin{abstract}
Abstrak: Tujuan penelitian ini adalah untuk mengembangkan Lembar Kerja Taruna berbasis Problem Centered Learning (PCL) yang valid dan praktis. Jenis penelitian ini merupakan penelitian Research and Development $(R \& D)$, yang menggunakan enam langkah penelitian yaitu potensi masalah, pengumpulan informasi, desain produk, validasi desain, perbaikan desain dan uji coba. Instrumen penelitian yang digunakan berupa angket validitas dan angket praktikalitas. Teknik analisis data yang digunakan untuk menguji kevalidan dan kepraktisan bahan ajar lembar kerja siswa yang dikembangkan adalah teknik analisis skala likert. Berdasarkan analisis data validasi oleh validator diperoleh nilai persentase rata-rata Lembar Kerja Taruna berbasis PCL adalah 83,6\% dikategorikan sangat valid. Hasil nilai praktikaliatas oleh taruna diperoleh sebesar 83,4\% dikategorikan sangat praktis. Berdasarkan analisis data dapat disimpulkan bahwa Lembar Kerja Taruna berbasis PCL yang dikembangkan sangat valid dan praktis.
\end{abstract}

Kata kunci: Problem Centered Learning, Lembar Kerja

\section{PENDAHULUAN}

Pendidikan merupakan salah satu kunci dalam mempersiapkan Sumber Daya Manusia (SDM) yang handal. Pendidikan diyakini akan dapat mendorong memaksimalkan potensi Taruna sebagai SDM untuk dapat bersikap kritis, logis, dan inovatif dalam menghadapi dan menyelesaikan permasalahan yang dihadapinya. Melalui pendidikan, manusia dapat mengembangkan diri maupun memberdayakan potensi alam dan lingkungan untuk kepentingan hidupnya (Basri, 2005). Pemerintah telah melakukan berbagai usaha untuk memperbaiki mutu pendidikan nasional, diantaranya yaitu melakukan penyempurnaan kurikulum. Penyempurnaan kurikulum memang harus dilakukan untuk merespon tuntutan globalisasi.

Salah satu bidang studi yang mempunyai peran yang sangat penting dalam perkembangan ilmu pengetahuan dan teknologi adalah fisika. Fisika merupakan salah 
satu cabang sains yang mendasari perkembangan teknologi maju dan konsep hidup harmonis dengan alam serta fisika mengajarkan peserta didik berfikir dan bekerja secara ilmiah. mempelajari gejala-gejala alam melalui serangkaian proses yang dikenal dengan proses ilmiah yang dibangun atas dasar sikap ilmiah dan hasilnya terwujud sebagai produk ilmiah yang tersusun atas tiga komponen penting yaitu konsep, prinsip, dan teori (Etherington, 2011). Pengajar merupakan faktor penting dalam proses pembelajaran. Seorang pengajar harus mampu menyajikan materi pelajaran dengan baik sehingga dapat dipahami oleh peserta didik serta dapat dicapai tujuan pembelajaran sesuai dengan tuntutan kurikulum (Depdiknas, 2008).

Salah satu bentuk persiapan pengajar sebelum mengajar yaitu merancang Lembar Kerja untuk peserta didik. Lembar Kerja adalah salah satu bentuk dari bahan ajar cetak yang merupakan lembaran-lembaran berisi instruksi yang dikemas sedemikian rupa dan harus dikerjakan oleh peserta didik sehingga mereka dapat menemukan suatu konsep dari materi yang dipelajari (Andriyatin, dkk, 2016; Utami, 2016). Berdasarkan observasi di lapangan, bahan ajar belum digunakan secara maksimal dalam proses pembelajaran fisika. Penggunaan bahan ajar, memungkinkan taruna belajar sendiri tanpa harus tergantung pada dosen. Selain itu, taruna dapat belajar tanpa harus terikat dengan tempat maupun waktu. Dalam proses pembelajaran itu sendiri ada beberapa model yang dapat digunakan untuk membantu proses pembelajaran salah satunya adalah model Problem Cetered Learning (PCL). Model PCL merupakan rangkaian aktivitas pembelajaran yang menekankan kepada proses penyelesaian masalah yang dihadapi secara ilmiah. Menurut Istarani (2014: 37) terdapat tiga ciri utama dari model PCL yaitu: Pertama, model PCL merupakan rangkaian kegiatan aktivitas pembelajaran, artinya dalam implementasi model PCL ada sejumlah kegiatan yang harus dilakukan Taruna. Model PCL tidak mengharapkan Taruna hanya sekedar mendengar, mencatat, kemudian menghafal materi pelajaran, akan tetapi melalui model PCL Taruna aktif berfikir, berkomunikasi, mencari dan mengolah data, dan akhirnya menyimpulkan. Kedua, aktivitas pembelajaran diarahkan untuk menyelesaikan masalah. Model PCL menempatkan masalah sebagai kata kunci dari proses pembelajaran. Artinya tanpa ada masalah tidak akan mungkin ada proses pembelajaran. Ketiga, pemecahan masalah dilakukan dengan menggunakan pendekatan berfikir secara ilmiah. Berfikir dengan menggunakan model ilmiah adalah proses berfikir deduktik dan induktif. Proses berfikir ini dilakukan secara sistematis dan empiris. Sistematis artinya berfikir ilmiah melalui tahapan-tahapan tertentu, sedangkan empiris artinya proses penyelesaian masalah didasarkan pada data dan fakta yang jelas. Sesuai dengan tujuan model PCL adalah untuk menumbuhkan sikap ilmiah, dari beberapa bentuk PCL yang dikemukakan para ahli, maka secara umum PCL bisa dilakukan dengan langkah-langkah: (1) menyadari masalah; (2) merumuskan masalah; (3) merumuskan hipotesis; (4) mengumpulkan data; (5) menguji hipotesis; (6) menentukan pilihan penyelesaian. Tujuan penelitian ini adalah mengembangkan sebuah Lembar Kerja Fisika berbasis model pembelajaran PCL yang valid dan praktis.

\section{METODE PENELITIAN}

Jenis penelitian yang digunakan adalah Research and Development (R\&D). Subjek uji coba dalam penelitian ini yaitu Taruna Jurusan Nautika dan Teknik Politeknik Pelayaran Sumatera Barat yang memprogram mata kuliah Fisika Terapan berjumlah 29 orang. Penelitian ini merupakan suatu metode penelitian yang digunakan untuk menghasilkan suatu produk tertentu dan menguji keefektifan produk tersebut (Sugiyono, 2014: 298). Langkah-langkah penggunan metode pengembangan (R\&D) ada sepuluh langkah. 
1. Potensi dan Masalah

2. Mengumpulkan Informasi

3. Desain Produk

4. Validasi Desain

5. Perbaikan Desain

6. Uji Coba Produk

7. Revisi Produk

8. Ujicoba Pemakaian

9. Revisi Produk

10. Pembuatan Produk Masal

Instrumen penelitian merupakan suatu alat yang digunakan untuk mengukur fenomena alam maupun sosial yang diamati. Instrument dalam penelitian ini menggunakan angket. Adapun angket yang digunakan yaitu angket penilaian validasi yang diisi oleh validator dan angket praktikalitas yang diisi oleh taruna.

\section{Angket Validasi}

Angket validasi merupakan instrumen yang digunakan untuk mengumpulkan data mengenai valid atau tidaknya Lembar Kerja yang dikembangkan. Lembar validasi yang dikembangkan mengacu pada indikator penilaian validitas isi, validitas konstruk dan validitas bahasa. Semua lembar validasi yang digunakan dalam penelitian ini terlebih dahulu divalidasi oleh dua orang dosen menggunakan lembar penilaian validasi.

\section{Angket Praktikalitas}

Angket praktikalitas merupakan instrumen yang digunakan untuk mengumpulkan informasi mengenai praktikalitas lembar kerja yang dikembangkan. Instrumen praktikalitas terdiri dari angket respon taruna terhadap praktikalitas. Angket praktikalitas ini dikembangkan mengacu pada indikator penilaian keterlaksanaan lembar kerja. Indikator penilaian dapat dilihat pada Tabel 1.

Tabel. 1. Komponen Indikator Penilaian Praktikalitas

\begin{tabular}{|c|c|c|}
\hline NO & Aspek & Indikator \\
\hline 1 & $\begin{array}{l}\text { Kelayakan kontruksi } \\
\text { (keadaan) }\end{array}$ & $\begin{array}{l}\text { 1. Gambar } \\
\text { 2. Daya tarik } \\
\text { 3. Warna }\end{array}$ \\
\hline 2 & Komponen bahasa & $\begin{array}{l}\text { 1. Bahasa dan tulisan } \\
\text { 2. Bentuk tulisan } \\
\text { 3. Tata bahasa }\end{array}$ \\
\hline 3 & Kelayakan isi & $\begin{array}{l}\text { 1. Mencantumkan tujuan pembelajaran } \\
\text { 2. Relevansi dengan KI, KD, danindikator } \\
\text { 3. Keilmiahan materi yang disampaikan } \\
\text { 4. Organisasi materi yang disampaikan }\end{array}$ \\
\hline
\end{tabular}

Semua angket praktikalitas yang digunakan dalam penelitian ini juga divalidasi terlebih dahulu dengan menggunakan lembar penilaian instrumen. Penilaian instrument ini sangat penting dilakukan agar data mengenai praktikalitas perangkat pembelajaran yang dihasilkan praktis digunakan.

Teknik analisis data yang digunakan untuk mengetahui valid atau tidak validnya suatu lembar kerja dapat dilihat dari data angket yang digunakan dalam bentuk skala Likert. 
Skala ini disusun dalam bentuk kategori positif sehingga pernyataan-pernyataan positif mendapat bobot tertinggi (Arikunto, 2002; Riduwan, 2006).

1. Sangat setuju (SS) memiliki bobot 5

2. Setuju (S) memiliki bobot 4

3. Biasa saja (BS) memiliki bobot 3

4. Tidak setuju (TS) memiliki bobot 2

5. Sangat tidak setuju (STS) memiliki bobot 1

\section{HASIL DAN PEMBAHASAN}

Bahan ajar yang dibuat dalam bentuk Lembar Kerja berbasis Model PCL. Lembar kerja yang dikembangkan terdapat beberapa komponen diantaranya adalah cover, kata pengantar, petunjuk belajar, sintak model pembelajaran PCL, standar kompetensi, kompetensi dasar, indikator, tujuan, pendahuluan, materi, kegiatan pratikum, uji kompetensi, dan kunci jawaban.

Pada bagian materi disajikan dengan menggunakan sintak model pembelajaran PCL dimana sintak dari model PCL ada enam yaitu penyajian masalah, rumusan masalah, rumusan hipotesis, mengumpulkan data, menguji hipotesis dan kesimpulan (Merrillv \& Gilbert, 2008). Pada bagian awal materi disajikan beberapa masalah yang berguna untuk merangsang daya fikir taruna, setelah itu terdapat rumusan masalah berupa beberapa pertanyaan yang akan diselesaikan oleh peserta didik. Pada bagian kegiatan praktikum juga disajikan dalam bentuk model pembelajaran PCL. Penyajian praktikum yang mengikuti tahapan PCL dapat membantu peserta didik dalam melakukan kegiatan praktikum yang dilakukan secara berkelompok (Potvin, dkk, 2010).

Data yang dideskripsikan pada penelitian ini adalah data yang diperoleh dari jawaban angket dosen yang berjumlah 3 orang dosen. Data yang diperoleh kemudian dianalisis sehingga diperoleh skor rata-rata valid seperti terlihat pada Tabel 2. Konten dan aspek bahan ajar yang dikembangkan harus dinilai dan diuji. Uji konten sangat menentukan kelayakan media pembelajaran sebelum digunakan dalam penelitian (Fahrudin, 2018). Media dinyatakan layak untuk digunakan apabila media tersebut telah memenuhi kriteria valid dan telah ditelaah dengan baik oleh validator atau penelaah yang kompeten dibidangnya.

Tabel 2. Hasil Validasi oleh Validator

\begin{tabular}{|l|l|c|c|c|}
\hline \multirow{2}{*}{ No } & \multirow{2}{*}{ Aspek yang dinilai } & \multicolumn{3}{|c|}{ Validator (\%) } \\
\cline { 3 - 5 } & & V1 & V2 & V3 \\
\hline 1 & Kelayakan kontruksi & 43,0 & 41,0 & 42,0 \\
\hline 2 & Komponen bahasa & 31,0 & 26,0 & 29,0 \\
\hline 3 & Kelayakan isi & 23,0 & 20,0 & 21,0 \\
\hline Jumlah & 97,0 & 87,0 & 92,0 \\
\hline Persentase \% & 88,2 & 79,1 & 83,6 \\
\hline Rata-rata & \multicolumn{3}{|c|}{$83,6 \%$} \\
\hline Kategori & \multicolumn{4}{|c}{ Sangat Valid } \\
\hline
\end{tabular}

Berdasarkan Tabel 2 didapatkan rata-rata validasi Lembar Kerja Taruna berbasis PCL oleh validator adalah $83,6 \%$. Walaupun demikian, validator memberikan beberapa saran guna menghasilkan Lembar Kerja Taruna yang lebih baik lagi. Saran yang diberikan validator terhadap Lembar Kerja sebagaimana pada Tabel 3. 
Tabel 3. Saran Validator dalam Validasi

\begin{tabular}{|ll|}
\hline \multicolumn{2}{|l|}{ Saran Validator } \\
\hline a. Sesuaikan dengan kurikulum yang digunakan \\
b. Ukuran rumus perlu diperbesar \\
c. Perhatikan penggunaan tanda baca dan ejaan bahasa \\
Indonesia \\
d. Pada halaman awal cantumkan kata pengantar dan \\
petunjuk penggunaan Lembar Kerja \\
e. Model yang digunakan harus lebih diperjelas \\
f. Langkah-langkah pembelajaran harus lebih \\
diperjelas \\
\hline
\end{tabular}

Lembar kerja yang dikembangkan harus dapat mengembangkan kemampuan berpikir peserta didik. Lembar kerja peserta didik sebaiknya disesuaikan dengan langkah-langkah pembelajaran PCL, sehingga perlu dikembangkan secara spesifik sesuai dengan model pembelajaran yang digunakan yaitu PCL. Lembar kerja yang dirancang meliputi serangkaian kegiatan yang harus dilakukan oleh taruna untuk memahami materi pelajaran yang dipelajari sesuai dengan langkah-langkah PCL. Menurut Nurliawati, dkk (2017) bahwa lembar kerja peserta didik yang dikembangkan tidak hanya menuntut kemampuan peserta didik dalam menyelesaikan sekumpulan soal, namun diharapkan dapat mengembangkan kemampuan berpikir peserta didik.

Data praktikalitas lembar kerja yang dikembangkan diperoleh berdasarkan tanggapan taruna. Data yang diperoleh kemudian dianalisis sehingga diperoleh skor rata-rata kepraktisan seperti yang terlihat pada Tabel 4.

Tabel 4. Hasil Praktikalitas Lembar Kerja Fisika Terapan berbasis PCL oleh Taruna

\begin{tabular}{|c|c|c|}
\hline No & Nama Taruna & Persentase (\%) \\
\hline 1. & T1 & 91,0 \\
\hline 2. & T2 & 89,0 \\
\hline 3. & T3 & 83,0 \\
\hline 4. & T4 & 77,0 \\
\hline 5. & T5 & 87,0 \\
\hline 6. & T6 & 79,0 \\
\hline 7. & T7 & 74,0 \\
\hline 8. & T8 & 100,0 \\
\hline 9. & T9 & 73,0 \\
\hline 10. & T10 & 81,0 \\
\hline 11. & T11 & 86,0 \\
\hline 12. & T12 & 84,0 \\
\hline 13. & T13 & 84,0 \\
\hline 14. & T14 & 89,0 \\
\hline 15. & T15 & 67,0 \\
\hline 16. & N1 & 80,0 \\
\hline 17. & N2 & 77,0 \\
\hline 18. & N3 & 73,0 \\
\hline 19. & N4 & 81,0 \\
\hline 20 & N5 & 89,0 \\
\hline 21 & N6 & 94,0 \\
\hline
\end{tabular}




\begin{tabular}{|c|c|c|}
\hline No & Nama Taruna & Persentase (\%) \\
\hline 22 & N7 & 87,0 \\
\hline 23 & N8 & 86,0 \\
\hline 24 & N9 & 91,0 \\
\hline 25 & N10 & 87,0 \\
\hline 26 & N11 & 81,0 \\
\hline 27 & N12 & 81.0 \\
\hline 28 & N13 & 77,0 \\
\hline 29 & N14 & 90,0 \\
\hline \multicolumn{2}{|c|}{ Persentase Keseluruhan } & 83,4 \\
\hline \multicolumn{2}{|c|}{ Kategori } & Sangat Praktis \\
\hline
\end{tabular}

Analisis kepraktisan dari data angket taruna secara keseluruhan dengan menggunakan skala Likert diperoleh nilai rata-rata kepraktisan Lembar Kerja Taruna berbasis PCL yaitu $83,4 \%$. Dari hasil pengolahan data angket dari dosen untuk validitas Lembar Kerja Taruna berbasis PCL, dan dari Taruna terhadap pratikalitasnya, dapat dijelaskan sebagai berikut:

1. Dosen

a. Kevalidan kontruksi

Kevalidan konstruksi yang dimaksud disini meliputi gambar, daya tarik dan warna yang digunakan pada Lembar Kerja Taruna berbasis PCL. Dari segi kevalidan konstruksi terdiri dari sepuluh aspek penilaian yang diisi oleh dosen. Hasil penilaian menunjukkan bahwa Lembar Kerja Taruna berbasis PCL yang dikembangkan memiliki gambar, daya tarik dan warna yang baik.

b. Komponen Bahasa

Komponen bahasa yang dimaksud disini meliputi bahasa, bentuk tulisan dan tata bahasa yang terdapat pada Lembar Kerja Taruna berbasis PCL. Dari segi komponen bahasa terdiri dari tujuh aspek penilaian yang telah diisi oleh dosen. Berdasarkan data yang diperoleh menunjukan bahwa Lembar Kerja Taruna berbasis PCL yang dikembangkan termasuk dalam kategori baik.

c. Kevalidan isi

Kevalidan isi yang dimaksud disini meliputi standar kompetensi, kompetensi dasar, indikator pembelajaran, tujuan pembelajaran, materi yang disampaikan dan organisasi materi yang disampaikan yang terdapat pada Lembar Kerja Taruna berbasis PCL. Dari segi kevalidan isi terdiri dari lima aspek penilaian yang telah diisi oleh dosen. Berdasarkan data yang diperoleh menunjukan bahwa Lembar Kerja Taruna berbasis PCL termasuk dalam kategori baik.

\section{Taruna}

Dari angket praktikalitas yang diberikan kepada taruna, maka untuk menghitung data kepraktisan ditinjau dari:

a. Bentuk

Bentuk yang dimaksud disini meliputi kualitas gambar, tulisan, komposisi warna, bahasa dan ukuran huruf yang digunakan. Dari segi bentuk terdiri dari 5 aspek penilaian dengan item nomor $1,2,3,4$, dan 5 yang telah diisi oleh taruna. Hasil penilaian menunjukan hasil yang sangat baik. Perpaduan teks dan gambar dalam Lembar Kerja Taruna berbasis PCL dapat menambah daya tarik serta dapat memudahkan pemahaman informasi yang disajikan dalam format verbal dan visual. 
b. Isi

Ditinjau dari segi isi yang terdapat pada angket peserta didik dengan item nomor 6 yang secara keseluruhan konten menunjukkan bahwa materi yang terdapat pada masing-masing bagian, mudah untuk dipahami oleh peserta didik. Materi yang disampaikan dapat dipahami dengan baik karena disajikan gambar-gambar yang dapat menuntun taruna menemukan konsep.

c. Motivasi

Ditinjau dari segi motivasi yang terdapat pada angket item nomor 7 menunjukkan bahwa Lembar Kerja berbasis PCL sangat memotivasi peserta didik dalam belajar. Bentuk kegiatan pengerjaan Lembar Kerja berbasis PCL juga dilakukan secara berkelompok. Kegiatan kelompok dapat menciptakan motivasi untuk bertanya antar taruna sehingga mereka dapat saling bertukar pikiran untuk memahami materi yang dipelajari.

Lembar kerja yang dikembangkan memenuhi kategori valid dan praktis berdasarkan penilaian oleh validator yang memvalidasi perangkat penelitian yang dikembangkan dan penilaian praktikalitas oleh taruna setelah pelaksanaan pembelajaran di kelas. Lembar kerja yang baik tentunya akan membantu peserta didik dalam belajar sehingga peserta didik merasa terbantu dalam memahami materi pelajaran (Fannie \& Rohati, 2014; Choo, dkk, 2011). Lembar kerja berbasis PCL dapat mengembangkan kemampuan taruna dalam menyelesaikan permasalahan belajar yang dihadapi karena dilengkapi dengan langkahlangkah yang runtun yang menuntut taruna untuk belajar dan berpikir dalam menyelesaikan permasalahan yang disajikan. Peserta didik akan senang dalam belajar apabila mereka merasa puas dengan penggunaan perangkat pembelajaran yang baik salah satunya adalah lembar kerja yang menarik (Asmawati, 2015; Mihardi, 2013).

\section{SIMPULAN DAN SARAN}

Berdasarkan hasil penelitian dan pembahasan maka simpulan dari penelitian pengembangan Lembar Kerja Taruna berbasis PCL untuk Taruna Nautika dan Teknik sangat valid dan praktis. Lembar Kerja berbasis PCL ini dapat digunakan sebagai sumber pembelajaran. Dari hasil penilaian dari segi validitas angket oleh validator didapatkan skor rata-rata $83,6 \%$ dikategorikan sangat valid sedangkan dari hasil praktikalitas yang dilakukan mendapatkan skor rata-rata 83,4\% yang dikategorikan sangat praktis. Sehingga Lembar Kerja Taruna berbasis PCL ini dapat digunakan dan dikembangkan secara lebih luas lagi dengan melihat juga aspek efektifitasnya.

\section{DAFTAR PUSTAKA}

Andriyatin, R., Rosidin, U., \& Suana, W. (2016). Pengembangan Lembar Kerja Siswa Model Problem Based Learning Materi Suhu dan Kalor. Jurnal Pembelajaran Fisika, 4(3).

Arikunto, S. (2002). Prosedur Penelitian Suatu Pendekatan Praktek. Jakarta: Pt. Rineka Cipta.

Asmawati, E. Y. (2015). Lembar Kerja Siswa (LKS) Menggunakan Model Guided Inquiry untuk Meningkatkan Keterampilan Berpikir Kritis dan Penguasaan Konsep Siswa. Jurnal Pendidikan Fisika, 3(1).

Basri, H. (2015). Paradikma Baru Sistem Pembelajaran. Bandung: Pustaka Sedia.

Choo, S. S., Rotgans, J. I., Yew, E. H., \& Schmidt, H. G. (2011). Effect of worksheet scaffolds on student learning in problem-based learning. Advances in health sciences education, 16(4), 517.

Depdiknas. (2008). Panduan Pengembangan Bahan Ajar. Jakarta BSNP. 
Etherington, M. (2011). Investigating Primary Science: A Problem Based Learning Approach. Australian Journal of Teacher Education, 36 (9): 53- 76.

Fahrudin, A. (2018). Development of Physics Summary Book as a Smartphone-Based Application and Its Effect on Elasticity Learning Achievement. Kasuari: Physics Education Journal (KPEJ), 1(1), 22-33.

Fannie, R. D., \& Rohati, R. (2014). Pengembangan Lembar Kerja Siswa (LKS) berbasis POE (Predict, Observe, Explain) pada Materi Program Linear Kelas XII SMA. Sainmatika: Jurnal Sains dan Matematika Universitas Jambi, 8(1).

Istarani. (2014). 58 Model Pembelajaran Inovatif. Perpustakaaan Nasional Republik Indonesia.

Merrill, M. D., \& Gilbert, C. G. (2008). Effective peer interaction in a problem-centered instructional strategy. Distance education, 29(2), 199-207.

Mihardi, S., Harahap, M. B., \& Sani, R. A. (2013). The effect of project based learning model with kwl worksheet on student creative thinking process in physics problems. Journal of Education and Practice, 4(25), 188-200.

Nurliawaty, L., Mujasam, M., Yusuf, I., \& Widyaningsih, S. W. (2017). Lembar Kerja Peserta Didik (LKPD) berbasis Problem Solving Polya. JPI (Jurnal Pendidikan Indonesia), 6(1), 72-81.

Potvin, P., Riopel, M., Masson, S., \& Fournier, F. (2010). Problem-centered learning vs. teaching-centered learning in science at the secondary level: An analysis of the dynamics of doubt. Journal of applied research on learning, 3(5), 1-24.

Riduwan. (2006). Belajar Mudah Meneliti untuk Guru-Karyawan dan Peneliti Permula. Bandung: Alfabeta.

Sugiyono. (2014). Metode Penelitian Kuantitatif Kualitatif dan $R \&$ D. Bandung: Alfabeta.

Utami, W. S. (2016). The Effectiveness of Geography Student Worksheet to Develop Learning Experiences for High School Students. Journal of Education and Learning, 5(3), 315-321.

Widyaningsih, S. W., \& Yusuf, I. (2018). Project Based Learning Model Based on Simple Teaching Tools and Critical Thinking Skills. Kasuari: Physics Education Journal (KPEJ), 1(1), 12-21. 